\title{
Editorial: Epistemic Vulnerability ${ }^{*}$
}

\section{GERRIE F. SNYMAN (UNISA)}

As this issue of Old Testament Essays was compiled and edited, a storm burst out around the presence of a statue of Cecil John Rhodes on the campus of the University of Cape Town. The debate that is developing around the presence of symbols related to the past brings to the fore our vulnerabilities.

Vulnerability is a human condition. Negatively it refers to the possibility of being harmed or wounded, either physically or emotionally. When one is open to injury, violation and denigration, there is a need for social justice where the perpetrating agent needs to reciprocate in order to restore the balance. In this restoration process the latter agent, in turn, is rendered vulnerable. Vulnerability is what connects human beings to each other, the basis for reciprocity, survival, prosperity, or simply just being. It is an enabling condition that makes it possible to love and to suffer.

Vulnerability is very much the subject matter in the first article of this year's first issue. Adu-Gyamfi reads Obadiah in terms of the ethnic conflicts within Africa and the notion of brotherhood with reference to Jacob and Esau. He regards them as being in a close relationship that saw them as neighbours and fellow Semites but not necessarily blood brothers. The notion of brotherhood in Ghana, is similarly based and draws on the geographical context when the term "brother" is used: two boys from the same mother as well as two people from the same country but from different tribes and places. What is important though is the moral burden the notion of brotherhood places upon a person. In Obadiah Edom is accused of an aggravated lack of brotherhood. But Adu-Gyamfi reminds the reader that one does not know whether this relationship of brotherhood was reciprocated by Edom. To him, though, Obadiah is illustrative of what happens when there is a lack of solidarity created by ethnic hatred.

Adamo's essay is written in response to his context's own vulnerability to a perceived coloniality of knowledge. Adamo wants to strengthen the epistemologies from which his community operates as a credible answer to what he sees as the hegemonic and ideological stranglehold of Eurocentric biblical scholarship. To that end he aims to provide a liberational and transformational hermeneutic.

Ellis writes on the interpretation of Rudolph Otto's concept of the mysterium tremendum in the book Das Heilige. His investigation of the notion of the fear of God in a text of Job and Qohelet relates to the idea of vulnerability. Apart from the context of vulnerability that generates the fear of God, Ellis sees a seeming correspondence between with Otto's views on the mysterium tremendum. Vul-

\footnotetext{
To cite: Gerrie F. Snyman, "Editorial: Epistemic Vulnerability," OTE 28/1 (2015): 9-10, DOI: http://dx.doi.org/10.17159/2312-3621/2015/v28n1a2
} 
nerability is, inter alia, about being open to not know. Ellis, in turn, argues that in the texts of Job and Qohelet he investigated, the notion of not being able to find / understand (מצא לא) stands in close proximity to the notion of fearing God (ירא).

Death seems to be the ultimate evidence of our vulnerability and life after death appears to overcome that decisive moment. Evans asks whether concepts of resurrection of the dead have had their origin in specific passages in the book of Ezekiel, and if so whether these concepts refer to Israel as a group or to individuals.

Gericke writes the dual causality principle which he defines as the assumption that for every significant state of affairs in the world of the text there are assumed to be both divine and human causes working. His aim is to show how complex the metaphysics of causality is and how reductionist the notion of dual causality has been in practice. Gericke intends to demonstrate the vulnerability of OT scholarship in this regard. Bernard Gosse unintentionally illustrates Gericke's explanation of the dual causality principle in explaining the process of rendering vulnerable the southern kingdom.

If vulnerability is not essentially a negative state, but also a condition of potential, hope enters the scene. Kotzé examines various aspects of hope in LXX Lamentations. According to him, the hope one reads about in LXX Lam 5:21 takes the form of an uncertain attitude of expectation regarding a desired future.

To foreclose vulnerability is to eradicate an important resource from which a human being takes direction. In the book of Nehemiah, vulnerability becomes quite instructive in understanding Nehemiah's memoirs. Leung Lai argues that memoirs are not only concerned with what happened, but also with how what happened is experienced by the writer. To her a memoir is not about what happened, but the person to whom things happened. In a memoir fuelled by emotion and physical sensations, it is the latter two that remain with the reader.

Spoelstra's reading of Jewish resilience in the book of Esther shows how resistance to vulnerability in a victim of colonial power creates a scenario in which the colonising other is rendered vulnerable in the same way as the imperial exercise of power once rendered the colonised vulnerable.

One aspect that needs attention in our scholarship is our epistemic vulnerability: the way we think is shaped by the ideologies and epistemology with which we grew up. Exploitation of other human beings (and nature) can be linked to particular epistemologies that create an arrogant independent invulnerable subject with an illusion of control.

Gerrie Snyman, Editor, Old Testament Essays. Department of Biblical and Ancient Studies, Unisa. Email: snymagf@unisa.ac.za or ote-editor@otwsaotssa.org.za. 